\title{
Petrology and petrogenesis of Kamtal Intrusion Eastern Azarbaijan, NW Ian
}

\author{
Mir Ali Asghar Mokhtari \\ School of Science, Tarbiat Modares University, \\ Tehran, Iran
}

\section{Mehrpartou}

Geosciences Research center, Geological Survey of Iran,

Tehran, Iran

\author{
H. Moinvaziri, M.R. Ghorbani \\ School of Science, Tarbiat Modares University, \\ Tehran, Iran
}

\begin{abstract}
The Kamtal Intrusion is located in Eastern Azarbaijan province, northwestern Iran, near the Armenian border. This body consists of an acidic part of monzogranitic composition, and an intermediate-basic part which is composed of quartz-monzonite and gabbro. The gabbro forms lenses within the intermediate rocks. Monzogranite has been intruded into the quartz-monzonite. Both monzogranites and quartz-monzonites are high-K calk-alkaline and metaluminous in composition and can be classified as I-type granitoids, while the gabbro has tholeiitic affinity.

Monzogranite and quartz-monzonite are characterized by LREE-rich patterns and high LREE/HREE ratios. The similarities of their REE patterns suggest a genetic relationship among these rocks. The geochemical characters of the gabbro types indicate two different patterns: a flat pattern with low LREE/HREE ratio, and a steep pattern with high LREE/HREE ratio. The former was probably produced by high melting ratio of a depleted mantle source, and the steep pattern probably was the result of a low melting ratio of this mantle source. Negative anomalies of $\mathrm{Nb}$ and $\mathrm{Ti}$ can be seen in all rock types of the Kamtal Intrusion, which is indicative of subduction zones. The comparison of trace element variations with granitoid rocks of different tectonic settings allows observing a similarity between the Kamtal Intrusion and Andean volcanic arc granitoids.

The Kamtal body is related to the VAG tectonic setting and was probably produced as a result of Khoy back-arc basin subduction beneath the Azerbaijan continental crust.
\end{abstract}

Keywords: Azarbaijan, Caucasus, geochemistry, granitoid, Kamtal, monzogranite, Qaradagh, quartz-monzonite, petrology

Addresses: M. A. A. Mokhtari, H. Moinvaziri, M. R. Ghorbani: Gisha bridge, Jalal-e-al-Ahmad Exp., Tehran Iran, e-mail: Mokhtari1031@gmail.com M. Mehrpartou: Meraj Ave., Azadi Sq., Tehran, Iran

Received: September 17, 2010; accepted: December 20, 2010 


\section{Introduction}

The Kamtal Intrusion is a part of the Qaradagh Batholith of OligoceneMiocene age. The outcrop of this batholith covers an area larger than $1,500 \mathrm{~km}^{2}$, in northwest of Iran and the Republics of Azerbaijan and Armenia. The area of the Iranian part of the batholith is $>500 \mathrm{~km}^{2}$ and is the largest intrusion in NW Iran. The Kamtal Intrusion covers an area about $30 \mathrm{~km}^{2}$, located in the southwestern part of the Qaradagh Batholith in eastern Azarbaijan province, NW Iran, near the Armenian border.

This paper deals with some unresolved questions of the petrology, geochemistry and petrogenesis of the Kamtal body (Qaradagh Batholith). The major aim of this study is to determine the evolution of the magma, based mainly upon the composition of the rocks along with a variety of other geologic data, including the results of mapping, petrography and mineral analyses.

\section{Geologic setting}

At a regional scale the studied area is the part of southeastern rim of the Miskhana-Zangezur Zone in the Lesser Caucasus. Based on Iranian geostructural classifications (Aghanabati 2004) the Kamtal Intrusion lies in the Central Iran Zone, which is characterized by abundant Tertiary magmatism (Fig. 1).

The Kamtal Intrusion of Oligocene age is intruded into Cretaceous flysch-type rocks (Figs 2, 3). This intrusion led to the formation of a wide contact aureole (Kamtal skarn) around the Kamtal body (Mokhtari 2009).

The oldest rocks exposed in the studied area are a sequence of Upper Cretaceous (Santonian-Maastrichtian) flysch-type rocks (limestone, siltstone, shale and mudstone) and Upper Cretaceous intermediate, calc-alkaline volcanic rocks (Mehrpartou 1997). Flysch-type rocks are located in the southern to western side, and volcanic rocks crop out in the eastern part of the Kamtal body. The boundary between the Kamtal body and volcanic rocks is faulted. The volcanic rocks are hydrothermally altered (sericitic, argillic, sillisified, sulfidized and limonitic).

\section{Research methodology}

Our research includes two parts: field work and laboratory investigations. Field work included geologic mapping, determination of the rock types, delineating of contacts and sampling. In the course of the laboratory work, petrographic investigations were carried out on 40 thin sections of the freshest rocks. Sixteen whole-rock samples were analyzed for major and trace elements using XRF and ICP-MS (Table 1). The analyses were carried out at the ALS Chemex Laboratory in Canada. The composition of some rock-forming minerals such as pyroxene, amphibole, and plagioclase were evaluated by electron probe micro-analysis in the facilities of the Czech Geological Survey. 


\section{Petrography and mineral composition}

The Kamtal Intrusion consists of an acidic and an intermediate-basic part (Mokhtari 2009). The acidic part is younger than the intermediate-basic one and was intruded into it. The acidic part is composed of monzogranite, while the intermediate-basic part includes quartz-monzonite and gabbro. The gabbro forms lenses within the quartz-monzonite.

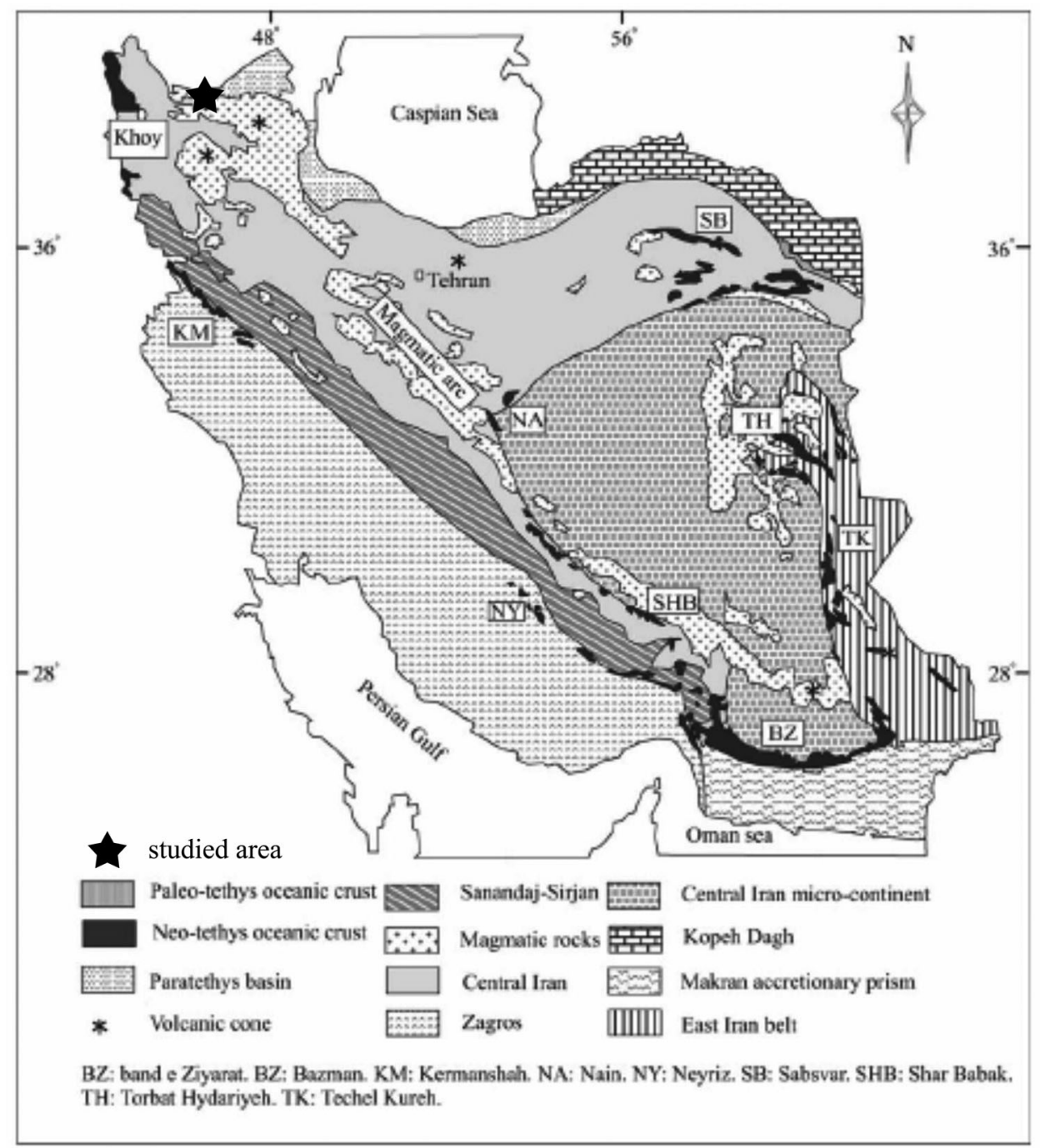

Fig. 1

Geologic map of Iran (Aghanabati 2004). Geologic and geographic location of the Kamtal Intrusion indicated on the map 


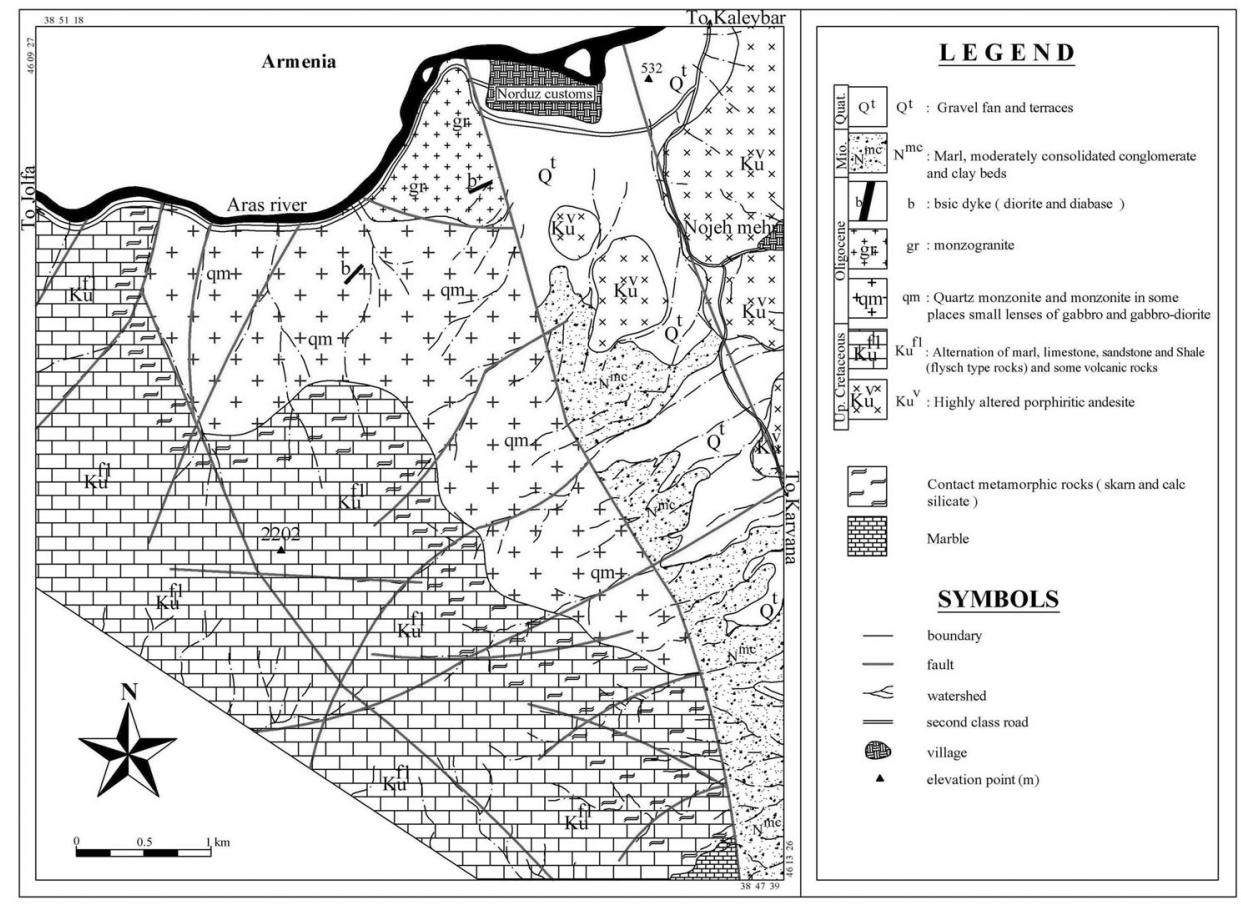

Fig. 2

Geologic map of Kamtal Intrusion (Mokhtari 2009)

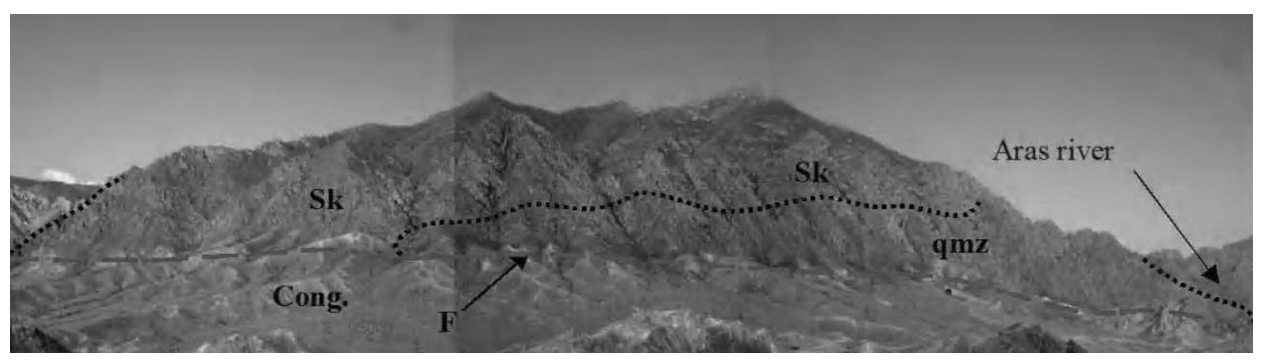

Fig. 3

A view of the quartz-monzonite body of the Kamtal Intrusion and Kamtal skarn aureole (view toward west). Sk - skarn aureole, F - fault, qmz: quartz-monzonite, Cong - Neogene conglomerate

\section{Gabbro}

Lenses of gabbro can be found within the quartz-monzonite body. They are coarse grained, dark in color and show gradational contact with quartzmonzonite. The gabbro is composed of plagioclase $\left(\mathrm{An}_{50-86}\right)$, clinopyroxene (diopside) and amphibole (ferro-tschermakite). Biotite is present as a minor 
phase in these rocks and generally altered to chlorite. Olivine $\left(\mathrm{Fo}_{78-80}\right)$ is present in some samples. Most of the clinopyroxenes have been altered to actinolite. Magnetite is a frequent minor phase in the gabbro. In some samples, xenomorphic magnetite (wormy shape) can be seen in the groundmass of plagioclase and clinopyroxene. This indicates that magnetite was formed in the final stage of crystallization. In some samples, worm-shaped magnetite aggregations are present with small crystals of plagioclase and clinopyroxene, which can be the result of immiscibility. The presence of primary biotite and amphibole in the gabbro indicates that the parent magma was rich in $\mathrm{H}_{2} \mathrm{O}$ (Mokhtari 2009).

\section{Quartz-monzonite}

Quartz-monzonite forms the main part of the Kamtal body. It is a coarsegrained rock, light gray to dark gray in color. It is composed of potassium feldspar (orthoclase), plagioclase $\left(\mathrm{An}_{29-39}\right)$, quartz, hornblende (Mg-hornblende), biotite and clinopyroxene (augite). Titanite, apatite, magnetite, rutile and zircon can be found as accessory phases, while epidote, actinolite, chlorite and sericite are secondary minerals. Most of the plagioclase is altered to epidote and sericite. Some of it shows embowed twinning, which can be the result of strain during the crystallization and emplacement of the intrusion (Shelly 1993). Perthite can be seen in some of samples of alkali feldspar. Some biotite grains have been altered to chlorite and epidote. Clinopyroxene is partially replaced by actinolitic amphibole in subsolvus conditions or by hornblende (Mg-hornblende) in magmatic conditions. In some places small euhedral clinopyroxene crystals can be observed within plagioclase grains, indicating that clinopyroxene crystallized before plagioclase. Idiomorphic crystals of titanite and magnetite are also abundant in these rocks. The presence of primary magnetite in mafic minerals such as pyroxene, hornblende, biotite and titanite indicates high oxygen fugacity in the parent magma (Sock et al. 1980).

Quartz-monzonite is cut by numerous green to light-green veins (Fig. 4). These veins are characterized by epidote, actinolite, quartz and garnet (Fig. 5). These veins are absent in the monzogranite stock, indicating

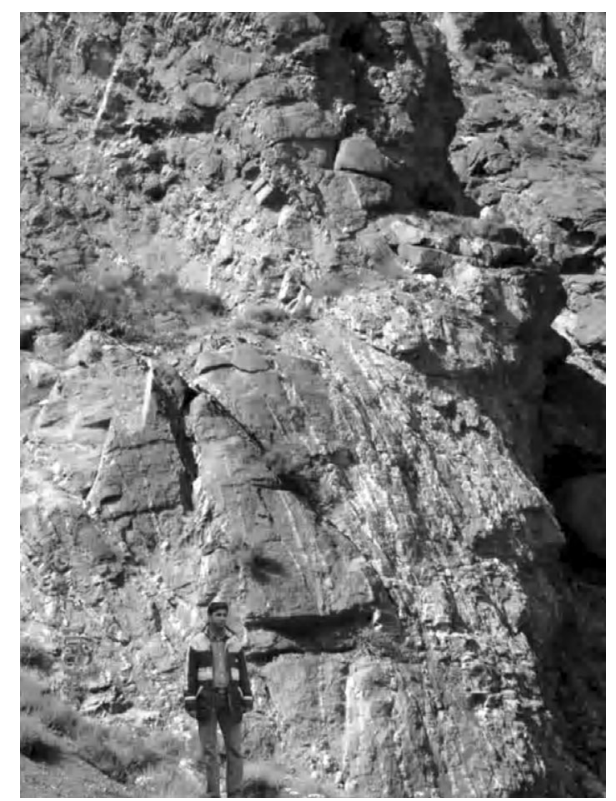

Fig. 4

A view of light-colored veins of epidote, actinolite, quartz and garnet cutting a darkcolored quartz-monzonite body 
84 M. A. A. Mokhtari et al.

Table 1

Major ( $\mathrm{wt} \%)$ and trace (ppm) element contents of selected samples from Kamtal intrusion. Samples signed by star symbol, were analyzed by ICP-MS method and other samples were analyzed by XRF method

\begin{tabular}{|c|c|c|c|c|c|c|c|c|}
\hline \multirow{2}{*}{$\begin{array}{c}\text { Rock type } \\
\text { S.N. }\end{array}$} & \multicolumn{8}{|c|}{ Quartz-monzonite } \\
\hline & pa.51 & pa.52* & pa.101* & pa.102a & Pa.102* & pa.110* & pa.120a & Pa.120b* \\
\hline $\mathrm{SiO}_{2}$ & 60.915 & 56.11 & 65 & 64.059 & 62.62 & 64.7 & 60.98 & 61.76 \\
\hline $\mathrm{TiO}_{2}$ & 0.776 & 0.817 & 0.5 & 0.547 & 0.56 & 0.51 & 0.67 & 0.69 \\
\hline $\mathbf{A l}_{2} \mathbf{O}_{3}$ & 14.943 & 15.648 & 15.1 & 14.601 & 14.9 & 14.65 & 15.32 & 14.54 \\
\hline $\mathrm{Fe}_{2} \mathrm{O}_{3} \mathrm{t}$ & 6.07 & 7.38 & 4.08 & 4.45 & 3.76 & 4.73 & 5.75 & 6.58 \\
\hline MnO & 0.109 & 0.144 & 0.089 & 0.094 & 0.14 & 0.08 & 0.11 & 0.12 \\
\hline MgO & 2.969 & 4.128 & 1.591 & 2.051 & 3.42 & 1.87 & 2.8 & 2.67 \\
\hline $\mathrm{CaO}$ & 7.363 & 8.939 & 4.225 & 4.764 & 5.28 & 4.55 & 6.84 & 7.09 \\
\hline $\mathrm{Na}_{2} \mathrm{O}$ & 2.721 & 3.302 & 4.07 & 3.496 & 3.59 & 3.7 & 3.2 & 2.84 \\
\hline $\mathbf{K}_{2} \mathbf{O}$ & 3.049 & 2.349 & 4.5 & 4.029 & 3.68 & 3.9 & 3.04 & 3.13 \\
\hline $\mathrm{P}_{2} \mathrm{O}_{5}$ & 0.239 & 0.238 & 0.163 & 0.211 & 0.2 & 0.16 & 0.25 & 0.21 \\
\hline Sum & 99.154 & 99.055 & 99.318 & 98.302 & 98.15 & 98.85 & 98.96 & 99.63 \\
\hline $\mathbf{B a}$ & 539.1 & 500 & 760 & 688.6 & 770 & 644 & 601.6 & 662 \\
\hline $\mathbf{R b}$ & 55.5 & 42 & 101.6 & 91.1 & 103 & 97.1 & 61.3 & 71.7 \\
\hline $\mathrm{Sr}$ & 388.1 & 587 & 451 & 453.7 & 646 & 417 & 409.7 & 434.6 \\
\hline Cs & 0.2 & 0.86 & 0.9 & 0.2 & 0.57 & 1.17 & 24.7 & 0.16 \\
\hline $\mathbf{G a}$ & 12.5 & 15.1 & 16.4 & 15.8 & 15.5 & 15.1 & 14.9 & 15.7 \\
\hline Ta & 0.2 & 0.24 & 0.26 & 0.5 & 0.29 & 0.27 & - & 0.17 \\
\hline $\mathbf{N b}$ & 1 & 5.2 & 5.5 & 1 & 6.49 & 4.9 & - & 2.73 \\
\hline Hf & 4.3 & 3.4 & 4.5 & 4.6 & 3.16 & 3.7 & 0.5 & 2.92 \\
\hline $\mathbf{Z r}$ & 81.1 & 98 & 130.4 & 175.8 & 83.3 & 148 & 120.3 & 142.9 \\
\hline $\mathbf{Y}$ & 4 & 19.2 & 17.2 & 9.2 & 22.3 & 16.9 & 13.1 & 22.5 \\
\hline Th & 1 & 4 & 8 & 1 & 6.22 & 7.92 & 3.2 & 2.02 \\
\hline $\mathbf{U}$ & - & 1.3 & 1.8 & - & 1.1 & 1.99 & - & 0.56 \\
\hline $\mathrm{Cr}$ & 79.7 & 53 & 57 & 89.8 & 100 & 70 & 70.8 & 78.6 \\
\hline $\mathbf{N i}$ & 7.7 & 21 & 6 & 8.3 & 13.4 & 9 & 11.4 & 26.3 \\
\hline Co & 12.3 & 27 & 11 & 5.9 & 3.5 & 12.1 & 22.2 & 19 \\
\hline Sc & 15 & 11.5 & 8.1 & 11.5 & 8.56 & 9.1 & 11.6 & 22.6 \\
\hline $\mathbf{V}$ & 145.4 & 244 & 99 & 93.6 & 68.37 & 113 & 118.2 & 119.5 \\
\hline $\mathrm{Cu}$ & 47.8 & 67 & 16 & 45.5 & 58 & 20 & 60.2 & 66.1 \\
\hline $\mathbf{P b}$ & 3 & 6 & 12 & 3 & 28 & 15 & 8 & 15.8 \\
\hline $\mathrm{Zn}$ & 40.7 & 67 & 47 & 48 & 82 & 52 & 59.9 & 442.9 \\
\hline La & 16.8 & 13.8 & 16.8 & 21.9 & 18.55 & 17.7 & 1.2 & 16.9 \\
\hline $\mathrm{Ce}$ & 72.2 & 27.8 & 33 & 89.5 & 32.08 & 32.4 & - & 35.79 \\
\hline Pr & - & 3.4 & 3.6 & - & 3.12 & 3.84 & - & 3.75 \\
\hline Nd & 1 & 14.8 & 14.3 & 1 & 14.41 & 14.2 & - & 14.32 \\
\hline Sm & 1 & 3.5 & 3.1 & 0.3 & 3.06 & 3.07 & - & 3.14 \\
\hline $\mathbf{E u}$ & 2 & 1.1 & 0.8 & 1.7 & 0.73 & 0.85 & 2 & 0.83 \\
\hline Gd & - & 3.4 & 3 & - & 3.7 & 3.31 & - & 3.33 \\
\hline $\mathbf{T b}$ & 1.9 & 0.6 & 0.5 & 1.2 & 0.6 & 0.49 & - & 0.52 \\
\hline Dy & - & 3.2 & 2.7 & - & 3.23 & 2.8 & - & 2.84 \\
\hline Ho & - & 0.7 & 0.6 & - & 0.66 & 0.62 & - & 0.61 \\
\hline $\mathbf{E r}$ & - & 2 & 1.7 & - & 1.48 & 1.85 & - & 1.76 \\
\hline $\mathbf{T m}$ & - & 0.3 & 0.3 & - & 0.28 & 0.28 & - & 0.31 \\
\hline $\mathbf{Y b}$ & 1.4 & 1.9 & 1.9 & 1.4 & 1.86 & 1.92 & - & 1.89 \\
\hline $\mathbf{L u}$ & - & 0.3 & 0.3 & - & 0.3 & 0.33 & - & 0.36 \\
\hline
\end{tabular}


Table 1 (cont.)

\begin{tabular}{|c|c|c|c|c|c|c|c|c|c|}
\hline \multirow{2}{*}{$\begin{array}{l}\begin{array}{c}\text { Rock } \\
\text { type }\end{array} \\
\text { S.N. }\end{array}$} & \multicolumn{5}{|c|}{ Gabbro } & \multicolumn{4}{|c|}{ Monzogranite } \\
\hline & pa.114* & pa.115 & pa.121* & pa.190* & Pa.191* & pa.55* & Pa.55b* & pa.170* & pa.171 \\
\hline $\mathrm{SiO}_{2}$ & 43.4 & 45 & 46.1 & 45.7 & 46.6 & 72 & 71.13 & 72.9 & 71.6 \\
\hline $\mathrm{TiO}_{2}$ & 0.93 & 0.42 & 0.57 & 0.8 & 1.07 & 0.25 & 0.25 & 0.23 & 0.24 \\
\hline $\mathrm{Al}_{2} \mathrm{O}_{3}$ & 16.1 & 16.8 & 7.38 & 17.1 & 12.2 & 14.363 & 14 & 14.25 & 13.69 \\
\hline $\mathrm{Fe}_{2} \mathrm{O}_{3} \mathrm{t}$ & 12.79 & 7.49 & 11.04 & 10.95 & 11.24 & 2.31 & 2.23 & 2.17 & 2.04 \\
\hline MnO & 0.09 & 0.13 & 0.2 & 0.21 & 0.21 & 0.078 & 0.073 & 0.08 & 0.05 \\
\hline MgO & 7.83 & 9.81 & 20.8 & 7.77 & 10.65 & 0.58 & 0.618 & 0.53 & 0.56 \\
\hline $\mathrm{CaO}$ & 15.45 & 17.21 & 9.01 & 13.7 & 14.01 & 2.462 & 2.526 & 2.33 & 2.52 \\
\hline $\mathrm{Na}_{2} \mathrm{O}$ & 0.91 & 0.8 & 1 & 1.84 & 1.44 & 3.666 & 3.545 & 3.59 & 3.68 \\
\hline $\mathbf{K}_{2} \mathbf{O}$ & 0.73 & 0.68 & 0.85 & 0.57 & 1.06 & 3.758 & 3.732 & 3.37 & 3.74 \\
\hline $\mathbf{P}_{2} \mathrm{O}_{5}$ & 0.02 & 0.02 & 0.08 & 0.05 & 0.61 & 0.069 & 0.077 & 0.06 & 0.05 \\
\hline Sum & 98.25 & 98.36 & 97.03 & 98.69 & 99.09 & 99.536 & 98.181 & 99.51 & 98.17 \\
\hline $\mathbf{B a}$ & 104 & 33.9 & 167.5 & 157 & 227 & 780 & 713 & 680 & 609.1 \\
\hline $\mathbf{R b}$ & 20.2 & 21.8 & 21.5 & 19.4 & 13 & 108.3 & 112.7 & 84.5 & 105.8 \\
\hline $\mathbf{S r}$ & 537 & 713.8 & 177 & 739 & 324 & 239 & 264.8 & 225 & 217.9 \\
\hline Cs & 0.7 & 3 & 0.83 & 0.64 & 1.38 & 0.42 & 0.2 & 0.46 & 14.1 \\
\hline $\mathbf{G a}$ & 16.9 & 14.8 & 8.2 & 17.8 & 12.9 & 19.1 & 14.1 & 14.7 & 14.7 \\
\hline $\mathbf{T a}$ & 0.1 & - & 0.2 & 0.5 & 0.2 & 0.24 & 0.25 & 0.2 & - \\
\hline $\mathbf{N b}$ & 0.6 & 2.2 & 2 & 2.9 & 3.44 & 4.7 & 4.5 & 4.9 & - \\
\hline Hf & 0.8 & - & 1.6 & 1.9 & 0.59 & 0.84 & 0.7 & 0.8 & 6.5 \\
\hline $\mathbf{Z r}$ & 22 & - & 54 & 39 & 24 & 136 & 142.7 & 115 & 107.1 \\
\hline $\mathbf{Y}$ & 8.4 & 14.1 & 11.2 & 17.2 & 16.8 & 26.7 & 14.2 & 9.7 & 23.1 \\
\hline Th & 0.38 & 0.5 & 1.28 & 1.26 & 5.58 & 8 & 3.79 & 8.3 & 13.7 \\
\hline $\mathbf{U}$ & 0.32 & - & 0.42 & 0.42 & 1.33 & 1.8 & 1.09 & 1.51 & - \\
\hline $\mathrm{Cr}$ & 20 & 87.9 & 1600 & 340 & 361 & 72 & 96.6 & 100 & 102.4 \\
\hline $\mathrm{Ni}$ & 71 & 67.4 & 680 & 116 & 42 & 6 & 4.85 & 10 & 6.3 \\
\hline Co & 38.2 & 27.4 & 86.8 & 44.1 & 42 & 5 & 3 & 5.2 & 2.7 \\
\hline Sc & 42 & 36.3 & 46 & 38 & 49 & 3.2 & 5.19 & 4.7 & 8.6 \\
\hline $\mathbf{V}$ & 497 & 144.4 & 184 & 257 & 279 & 33 & 38.5 & 11 & 26.8 \\
\hline $\mathrm{Cu}$ & 6 & 14.2 & 62 & 51 & 14 & 11 & 20.5 & 8 & 9.3 \\
\hline $\mathbf{P b}$ & 13 & 16.4 & 10 & 38 & 12 & 2 & 3 & 8 & 68.6 \\
\hline $\mathrm{Zn}$ & 58 & 49 & 97 & 76 & 59 & 21 & 26.8 & 27 & 21.3 \\
\hline $\mathbf{L a}$ & 4.5 & - & 7.6 & 6 & 5.61 & 17.4 & 12.8 & 16.7 & 0.5 \\
\hline $\mathrm{Ce}$ & 9 & - & 15 & 13.9 & 16.66 & 28.6 & 27.7 & 27.6 & - \\
\hline $\operatorname{Pr}$ & 1.2 & - & 1.94 & 2.2 & 2.39 & 2.8 & 2.87 & 2.82 & - \\
\hline Nd & 5.3 & - & 7.9 & 11 & 10.19 & 9.8 & 10.03 & 10.1 & - \\
\hline Sm & 1.54 & - & 1.99 & 3.57 & 2.83 & 1.7 & 1.85 & 2.24 & - \\
\hline $\mathbf{E u}$ & 0.59 & 0.5 & 0.65 & 1.18 & 1.2 & 0.6 & 0.6 & 0.73 & 2.7 \\
\hline Gd & 1.69 & - & 2.27 & 3.84 & 3.46 & 1.7 & 1.8 & 2.48 & - \\
\hline $\mathbf{T b}$ & 0.3 & - & 0.37 & 0.63 & 0.69 & 0.3 & 0.37 & 0.38 & - \\
\hline Dy & 1.53 & - & 2.03 & 3.83 & 3.74 & 1.5 & 1.4 & 2.07 & - \\
\hline Ho & 0.33 & - & 0.43 & 0.84 & 0.82 & 0.3 & 0.4 & 0.53 & - \\
\hline $\mathbf{E r}$ & 0.91 & - & 1.18 & 2.35 & 2.13 & 1.1 & 1.15 & 1.63 & - \\
\hline $\mathbf{T m}$ & 0.12 & - & 0.18 & 0.42 & 0.45 & 0.2 & 0.24 & 0.32 & - \\
\hline $\mathbf{Y b}$ & 0.69 & 3.3 & 1.05 & 2.39 & 2.58 & 1.4 & 1.48 & 2.21 & 6.2 \\
\hline $\mathbf{L u}$ & 0.11 & - & 0.16 & 0.36 & 0.37 & 0.2 & 0.22 & 0.38 & - \\
\hline
\end{tabular}



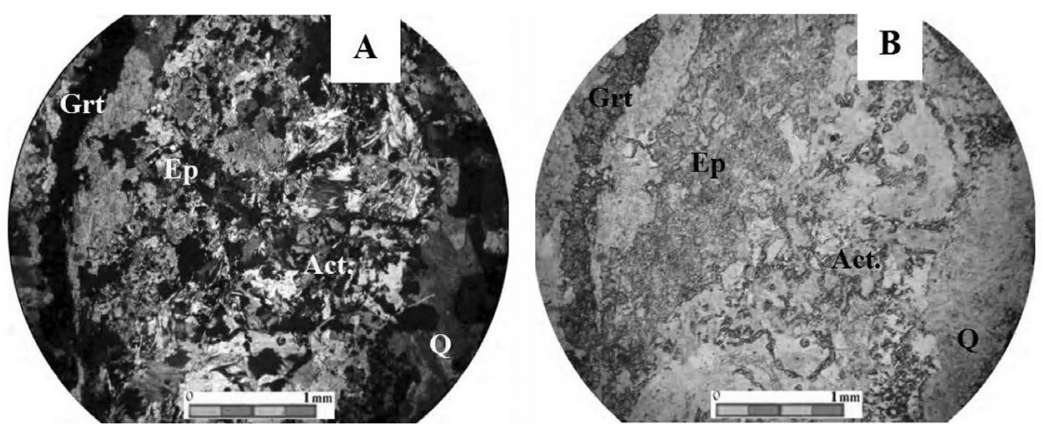

Fig. 5

Sequence of garnet, epidote, actinolite and quartz from the rim to center of vein. A) Crossed Polars. B) Plan-Polarized Light. Grt - garnet, Ep - epidote, Act - actinolite, Q - quartz

that they were intruded into quartz-monzonite before the monzogranite intrusion (Mokhtari 2009). The veins show gradational contact with quartzmonzonite, which suggests that they intruded before the complete crystallization of the host rock. According to Mirmohamadi (1995) the veins belong to the intrusion of granite stock. On the basis of field observations and petrographic studies, these veins might have crystallized from hydrothermal fluids rich in $\mathrm{CO}_{2}$ and $\mathrm{CaO}$ in quartz-monzonite (Mokhtari 2009). In this way minerals such as epidote, actinolite and garnet were formed.

\section{Monzogranite}

Monzogranite crops out on both sides of the Aras River as a small stock (Fig. 6). It is a fine-grained leucocratic rock, containing quartz, potassium feldspar and plagioclase $\left(\mathrm{An}_{28-30}\right)$ with some hornblende and biotite. Graphic texture is present in the upper parts of the monzogranite stock and near the contact with the intermediate part. In the field monzogranite includes abundant xenoliths of different shapes (Fig. 7A). Some of the xenoliths have many quartz-feldspatic amygdales (Fig. 7B). Mirmohamadi (1995) suggests that these xenoliths and amygdales are the result of magma mixing (diorite with granite). Our

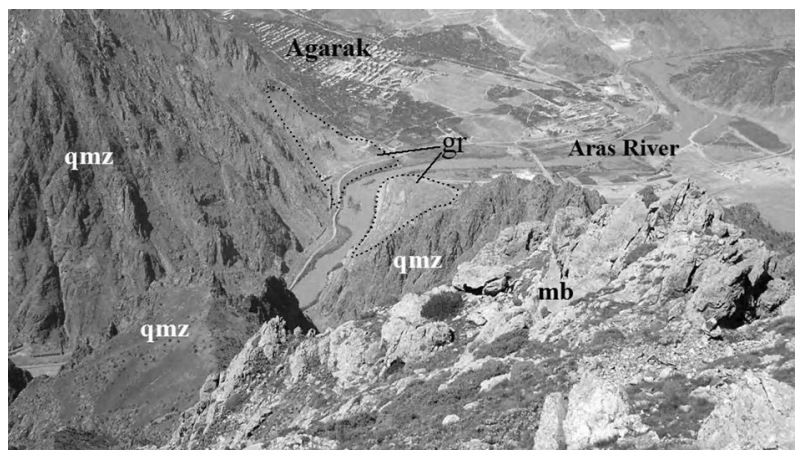

Fig. 6

A view of monzogranite and quartz-monzonite bodies on both side of the Aras River (view toward northeast). mb - marble, gr - monzogranite, qmz quartz-monzonite 

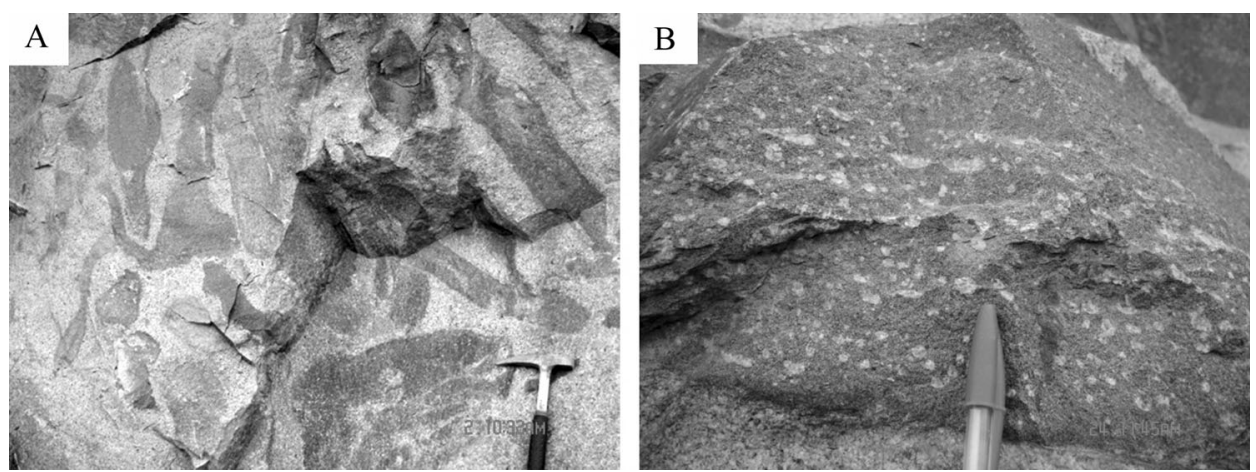

Fig. 7

A) abundant xenoliths of different shapes within the monzogranite, B) quartz-feldspatic amygdales within xenolith

petrographic studies indicate that the xenoliths are fragments of volcanic rocks of andesitic composition that underwent partial melting and feldspatization.

\section{Whole rock geochemistry}

Studies of variation diagrams for all rocks of the Kamtal Intrusion (major and trace elements) indicate three separate sets, meaning that gabbro, quartzmonzonite and monzogranite may have had different origins.

All rocks plot within the sub-alkaline field (Fig. $8 \mathrm{~A}$ ) in the $\mathrm{SiO}_{2}$ vs. $\mathrm{Na}_{2} \mathrm{O}+\mathrm{K}_{2} \mathrm{O}$ diagram (Irvine and Baragar 1971). In the triangular AFM diagram (Irvine and Baragar 1971), monzogranite and quartz-monzonite plot within the calc-alkaline field and gabbro plots within the tholeiitic field (Fig. 8B). In the $\mathrm{K}_{2} \mathrm{O}$ vs. $\mathrm{SiO}_{2}$ diagram (Rickwood 1989) granitoid rocks plot within the high-K calc-alkaline field and gabbro plots within the medium-K calc-alkaline field (Fig. 9).
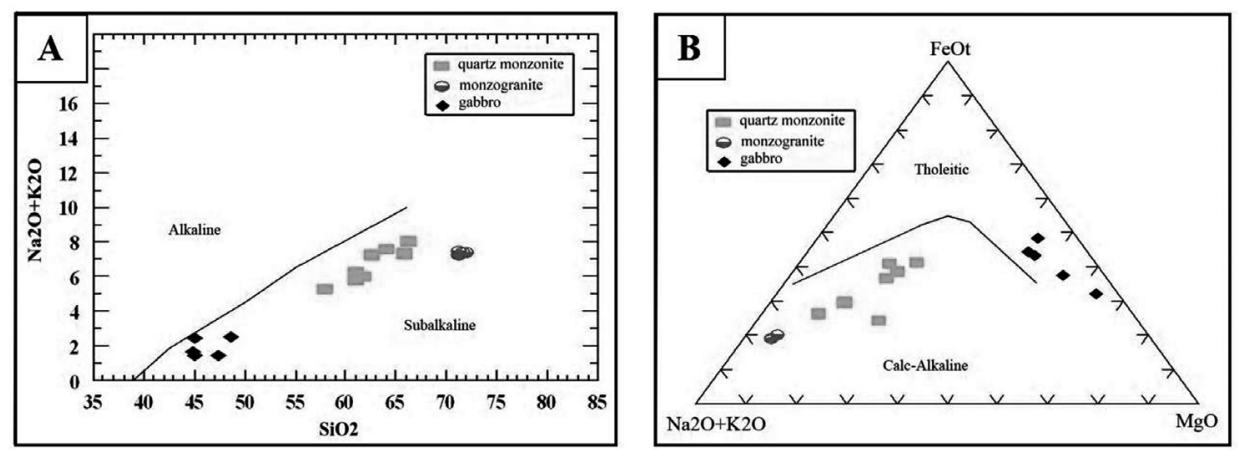

Fig. 8

A) Samples of the Kamtal Intrusion on $\mathrm{SiO}_{2}$ vs. $\mathrm{Na}_{2} \mathrm{O}+\mathrm{K}_{2} \mathrm{O}$ diagrams, B) Samples of the Kamtal Intrusion on an AFM diagram 


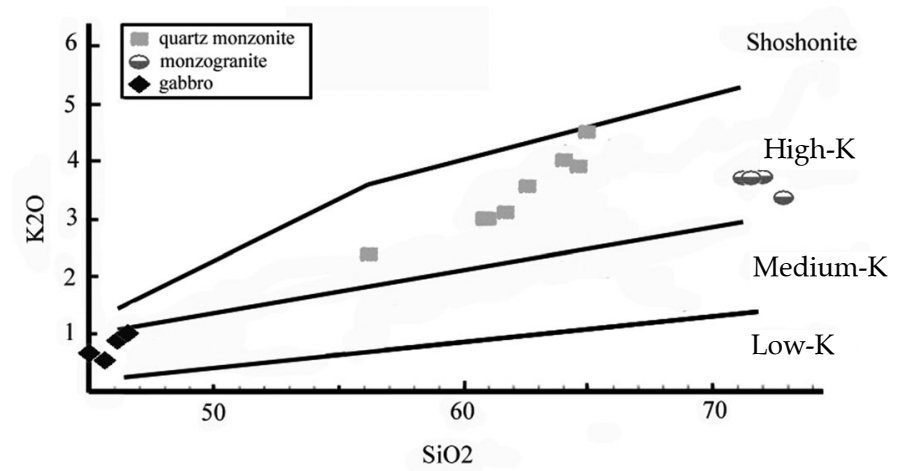

Fig. 9

Samples of the Kamtal Intrusion on a $\mathrm{SiO}_{2}$ vs. $\mathrm{K}_{2} \mathrm{O}$ diagram (Rickwood 1989)

The composition of biotite is different in the alkaline, calc-alkaline and peraluminous magmas (Abdel-Rahman 1994). The $\mathrm{FeO} / \mathrm{MgO}$ ratio of biotite in the Kamtal granitoids, and diagrams such as $\mathrm{Al}_{2} \mathrm{O}_{3}$ vs. $\mathrm{MgO}, \mathrm{Al}_{2} \mathrm{O}_{3}$ vs. $\mathrm{FeO}$ and $\mathrm{MgO}-\mathrm{FeO}-\mathrm{Al}_{2} \mathrm{O}_{3}$ triangular diagrams (Fig. 10), indicate that the parent magmas of Kamtal granitoids had calc-alkaline affinity.

The samples of monzogranite and quartz-monzonite have an $\mathrm{A} / \mathrm{CNK}$ ratio \{molar $\left.\mathrm{Al}_{2} \mathrm{O}_{3} /\left(\mathrm{CaO}+\mathrm{K}_{2} \mathrm{O}+\mathrm{Na}_{2} \mathrm{O}\right)\right\}$ between $0.65-0.96$ and plot within the metaluminous field in the A/NK vs. A/CNK diagram (Maniar and Piccoli 1989).
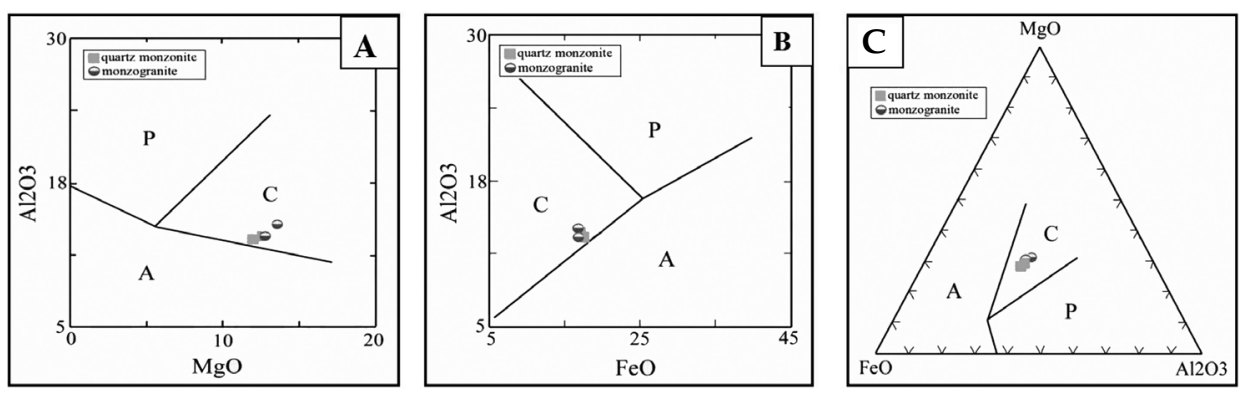

Fig. 10

Samples of the Kamtal Intrusion on Abdel-Rahman (1994) diagrams: A) $\mathrm{MgO}$ vs. $\mathrm{Al}_{2} \mathrm{O}_{3}$ diagram, $\mathrm{B}$ ) $\mathrm{FeO}$ vs. $\mathrm{Al}_{2} \mathrm{O}_{3}$ diagram, C) FeO-MgO- $\mathrm{Al}_{2} \mathrm{O}_{3}$ triangular diagram. A - alkaline, $\mathrm{C}$ - calc alkaline, $\mathrm{P}-$ peraluminous

Based on mineralogical and geochemical criteria, they can be regarded as Itype granitoids. These criteria include:

1. Hornblende, biotite, titanite and magnetite are abundant in these rocks while minerals such as muscovite, garnet, andalusite and sillimanite are absent.

2. The Kamtal Intrusion is composed of gabbro, quartz-monzonite and monzogranite.

3. $\mathrm{SiO}_{2}$ content varies between $43-73 \mathrm{wt} \%$. 
4. There are some mafic microgranular enclaves (Didier et al. 1982) while micaceous enclaves (restites) are missing.

5 . They are metaluminous and normally contain no corundum.

6. In the $\mathrm{SiO}_{2}$ vs. A/CNK diagram (Chappell and White 1974) and in the $\mathrm{SiO}_{2}$ vs. $\mathrm{Zr}$ diagram (Collins et al. 1980) they plot within I-type field (Fig. 11).

7. In the $\mathrm{P}_{2} \mathrm{O}_{5}$ vs. $\mathrm{SiO}_{2}$ diagram (Chappell and White 1992), $\mathrm{P}_{2} \mathrm{O}_{5}$ content decreases with increasing $\mathrm{SiO}_{2}$ in granitoids.

8. Granitoids plot within the I-type granitoid fields in the triangular ACF diagram (Chappell and White 1992).
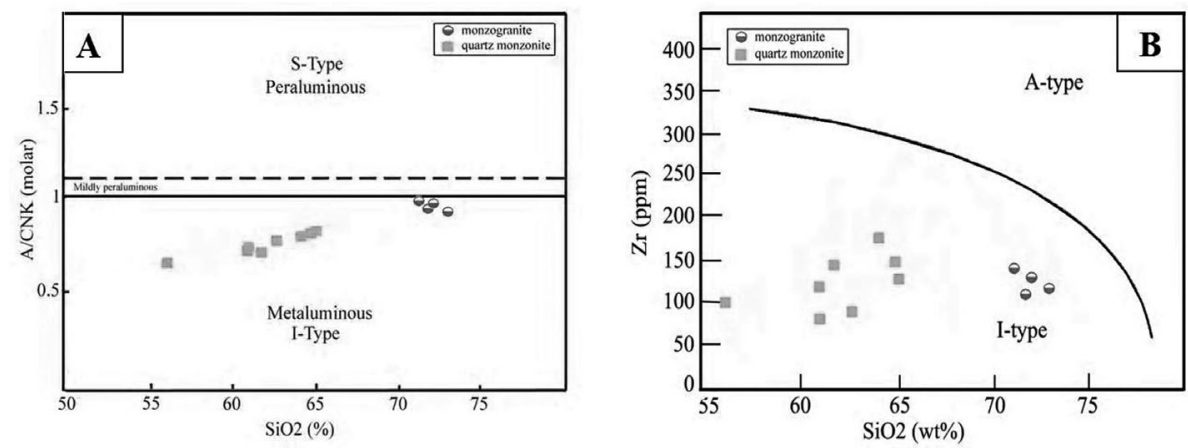

Fig. 11

A) Samples of the Kamtal Intrusion on an $\mathrm{A} / \mathrm{CNK}$ vs. $\mathrm{SiO}_{2}$ diagram (Chappell and White 1974), B) Samples of the Kamtal Intrusion on a $\mathrm{Zr}$ vs. $\mathrm{SiO}_{2}$ diagram (Collins et al. 1980)

The chondrite-normalized REE patterns of monzogranite and quartzmonzonite are shown in Fig. 13. Both groups show a LREE-rich pattern and high LREE/HREE ratio. Their depletion in HREE is consistent with hornblende fractionation. Quartz-monzonites have flat MREEs and HREEs patterns with negative Eu anomalies (Fig. 12A). The negative anomalies of $\mathrm{Eu}$ are consistent with plagioclase fractionation. Monzogranite shows a concave pattern without
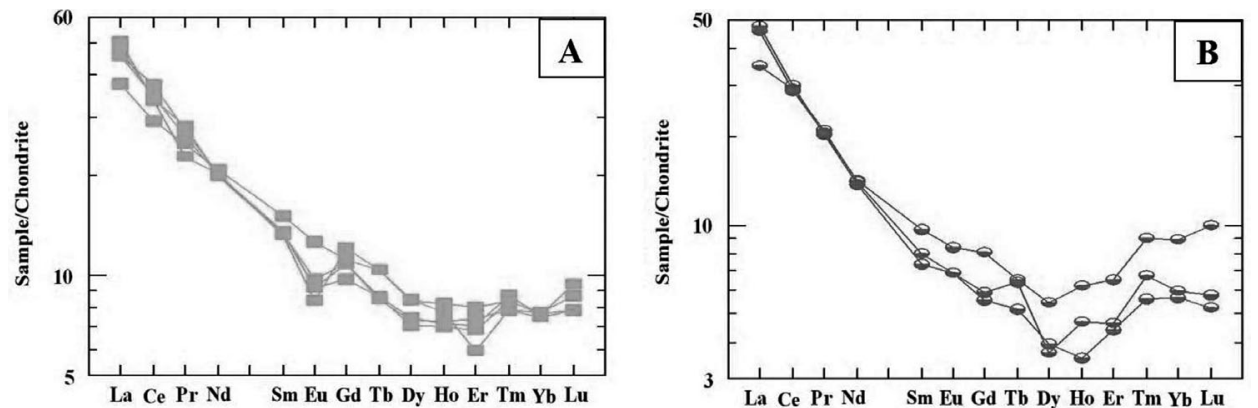

Fig. 12

A) Chondrite-normalized REE pattern in quartz monzonite, B) Chondrite-normalized REE pattern in monzogranite 

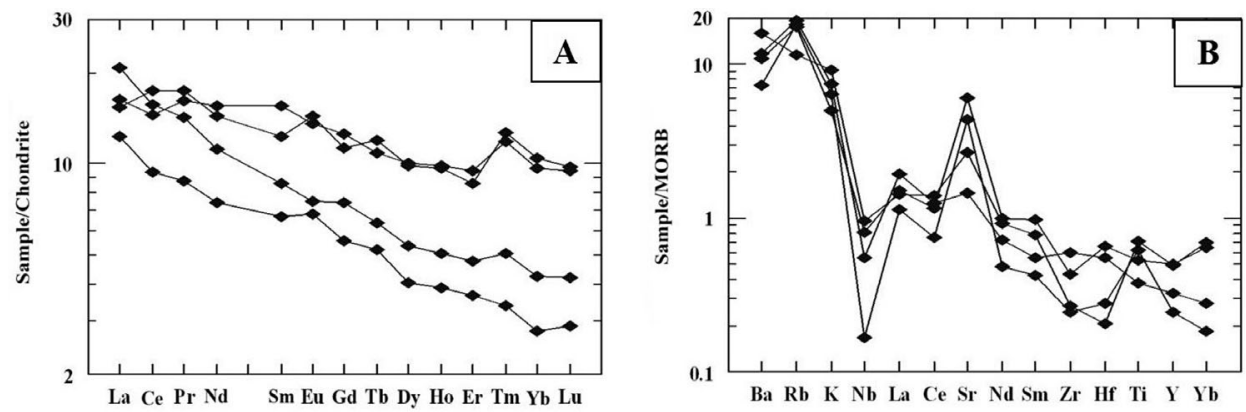

Fig. 13

A) Chondrite-normalized REE pattern in gabbro, B) MORB-normalized incompatible rare elements pattern in gabbro

Eu anomalies (Fig. 12B). Gabbro exhibits two different patterns (Fig. 13A): 1. flat pattern with low LREE/HREE ratio. 2. Steep pattern with high LREE/HREE ratio. Samples with flat patterns were probably produced from high-rate partial melting of depleted mantle. The MORB-normalized trace element patterns of the gabbro indicate a depletion of $\mathrm{Nb}, \mathrm{Zr}, \mathrm{Hf}, \mathrm{Ti}, \mathrm{Y}$ and $\mathrm{Yb}$ relative to mid-ocean ridge basalt and an enrichment of some elements (such as $\mathrm{Rb}, \mathrm{K}, \mathrm{Ba}$ and $\mathrm{Sr}$ ) that can be transferred by fluids to the magma (Fig. 13B). This indicates that fluids released from subducted oceanic crust played an important role during the formation of the basic magma in this area.

The primitive mantle-normalized incompatible trace element patterns of the quartz-monzonite and monzogranite are similar to each other (Fig. 14). These patterns show high enrichment of LILE, with negative anomalies of $\mathrm{Nb}$, $\mathrm{Ta}$ and $\mathrm{Ti}$ and a positive anomaly of $\mathrm{Zr}$. Negative anomalies of $\mathrm{Nb}$ and $\mathrm{Ti}$ are indicative of a subduction setting (e.g. Wilson 1989; Sajona et al. 1996). Also, Sajona et al. (1996) suggest that enrichment of $\mathrm{Rb}$ and $\mathrm{K}$ are indicative of subduction settings.
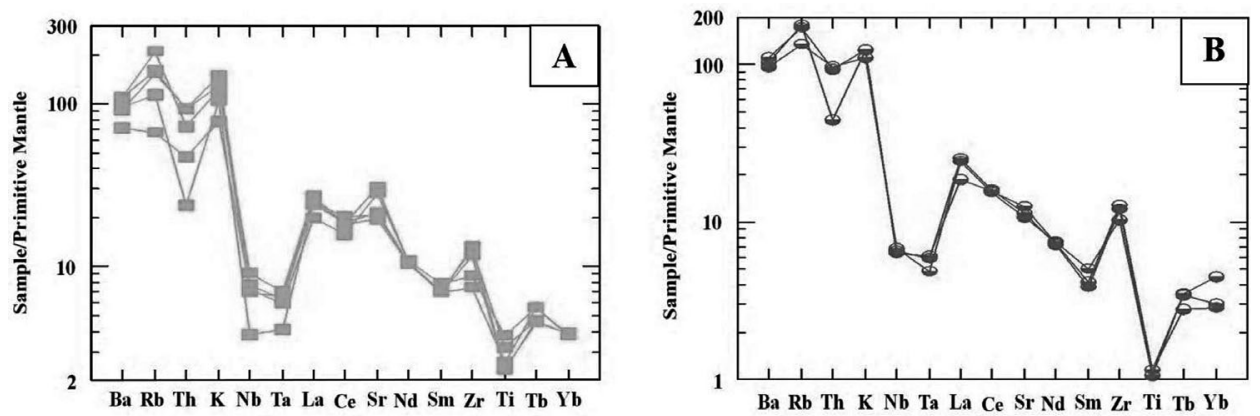

Fig. 14

A) Primitive mantle-normalized incompatible rare elements pattern in quartz monzonite, B) Primitive mantle-normalized incompatible rare elements pattern in monzogranite 
Subduction-related enrichment in the source region of the melt in the case of the Kamtal Intrusion can also be observed in a $\mathrm{Th} / \mathrm{Yb}$ vs. Ta/ $\mathrm{Yb}$ diagram (Fig. 15), which displays source variations and crustal contamination effects (Pearce 1982). All rocks of the Kamtal Intrusion show differences toward higher $\mathrm{Th} / \mathrm{Yb}$ ratios. This feature indicates a lithospheric mantle source enriched by a subduction component.

\section{Fig. 15}

Samples of the Kamtal Intrusion on a Th/ $\mathrm{Yb}$ vs. Ta/Yb diagram (Pearce 1982). All rocks of the Kamtal Intrusion show a trend parallel to the $\mathrm{Th} / \mathrm{Yb}$ axis and toward higher $\mathrm{Th} / \mathrm{Yb}$ ratios, indicating subduction-related enrichment in the source region of the melt

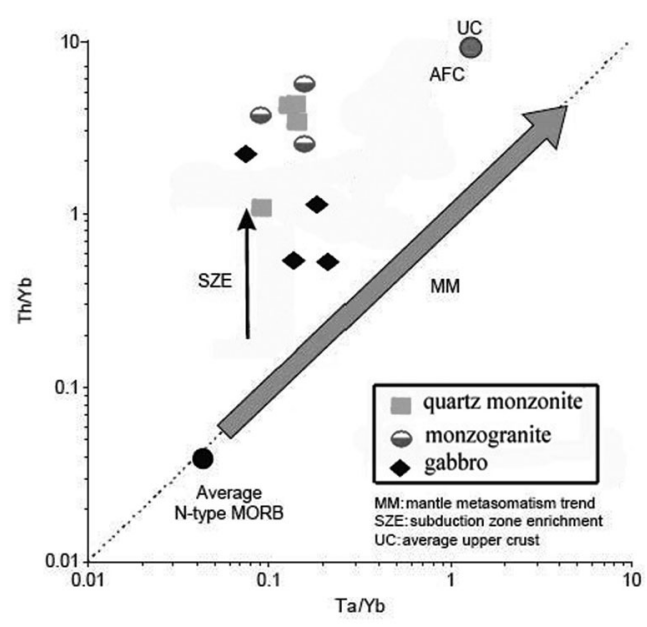

\section{Tectonic setting}

Samples from the Kamtal quartz-monzonite plot within the pre-plate-collision field in the tectonic discrimination diagram of Batchelor and Bowden (1985), but samples of monzogranite plot within the syn-collision field (Fig. 16A). All rock types of the Kamtal Intrusion plot within the volcanic arc field in the Pearce (1996) tectonic discrimination diagram (Fig. 16B). In this diagram, some samples plot within the common field of volcanic arc granites and post-collision granites. In order to discriminate between these two groups Muller and Groves (1997) diagrams were used. In this diagram all rocks plot within the continental arc setting (Fig. 16C). Monzogranite contains more $\mathrm{Zr} / \mathrm{TiO}_{2}$ than 400 ; therefore it plots outside of the diagram. Also, in Fig. 16D (Thieblemont and Tegyey 1994), the samples of the Kamtal Intrusion plot within subduction-related settings.

On the basis of the Barbarin (1999) classification, quartz-monzonite and monzogranite of the Kamtal Intrusion can be classified as ACG (amphibolebearing calc-alkaline granitoids) and KCG (K-rich calc-alkaline granitoids) granitoids. According to Barbarin (1999) the ACG granitoids were formed in a subduction setting, while the KCG granitoids were formed in a transitional setting during the change from compressional to tensional regime.

Meinert (1993) suggested that different kinds of skarn deposits (such as $\mathrm{Fe}, \mathrm{Cu}$, etc.) form in specific tectonic settings. The skarn aureole in the studied area 

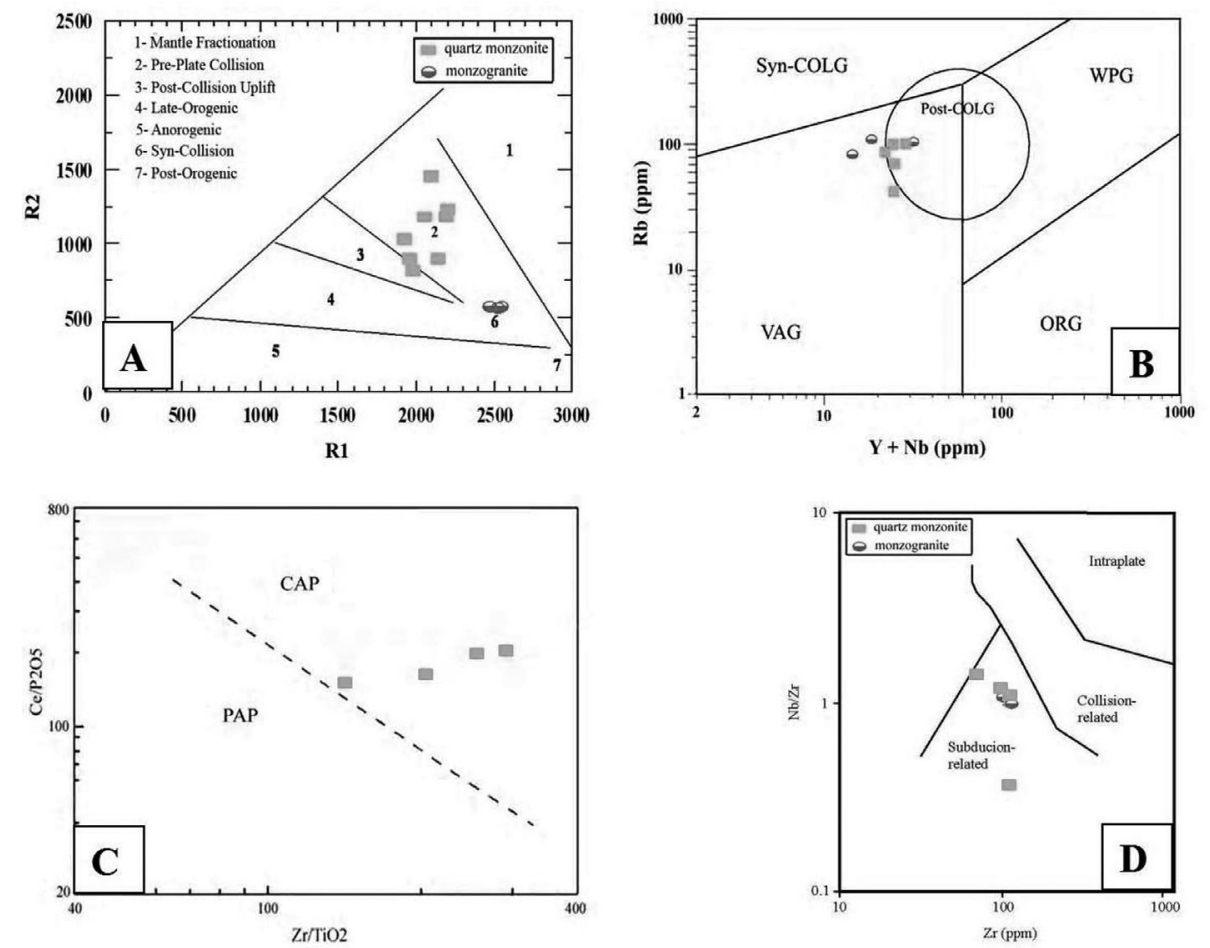

Fig. 16

Samples of Kamtal granitoids on some tectonic discrimination diagrams. A) Batchelor and Bowden (1985), B) Pearce (1996), C) Muller and Groves (1997). Symbols in all diagrams are the same. D) $\mathrm{Nb} / \mathrm{Zr}(\mathrm{n})$ vs. Zr diagram (Thieblemont and Tegyey 1994). (n), N-MORB-normalized values (Sun and McDonough 1989)

shows Fe-Cu mineralization. This kind of skarn forms in the subduction-related settings (Meinert 1993). The Kamtal Intrusion was therefore formed in a subduction-related setting.

A comparison of the chondrite-normalized incompatible rare element patterns of Kamtal quartz-monzonite and monzogranite with patterns of granitoids from different tectonic settings indicates a similarity between the Kamtal granitoids and Andean granitoids (Fig. 17). Therefore, it can be concluded that the Kamtal Intrusion was formed in a subduction-related setting.

\section{Tectonomagmatic model}

As mentioned before, the Kamtal Intrusion is a part of the Qaradagh Batholith, located to the south of the Sevan-Akera ophiolitic zone in the Lesser Caucasus. Based on the Iranian geostructural classification the Kamtal Intrusion belongs to the Alborz-Azerbaijan magmatic belt in NW Iran. 
Fig. 17

Comparison of Chondritenormalized REE patterns of Kamtal granitoids with Andean granite

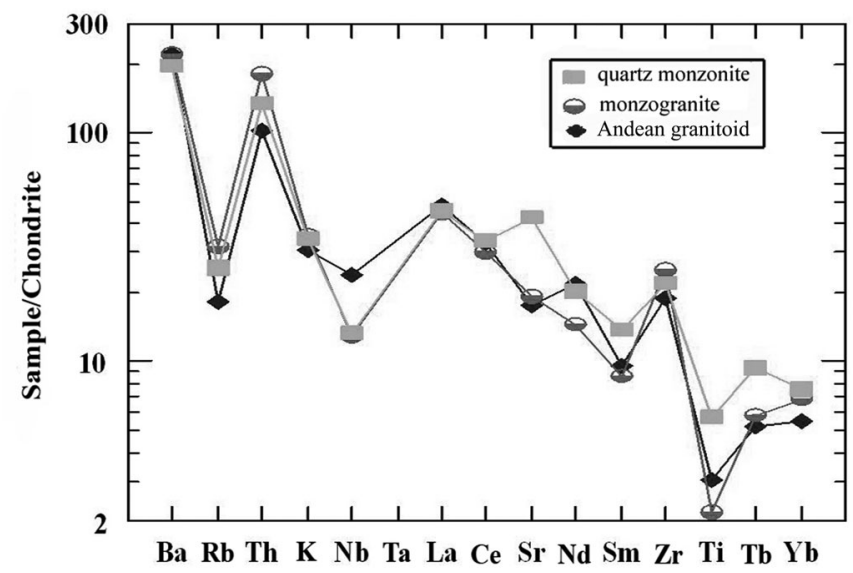

According to Alavi (1996) the Urumiyeh-Dokhtar (Sahand-Bazman) magmatic belt is an island arc that was built up during the subduction of the Neotethys oceanic crust. He suggested that the Alborz-Azerbaijan Tertiary magmatism is the result of the subduction of the oceanic back-arc basin of the Urumiyeh-Dokhtar island arc to the northwest beneath the Alborz-Azerbaijan micro-continent. On the other hand, some Iranian and other geologists (Hassanipak et al. 2000; Juteau 2003; Ghazi et al. 2003; Khalatbari-Jafari et al. 2003; Azizi and Jahangiri 2008) suggest that there was an oceanic basin in the Khoy area that was subducted to the northeast beneath the Alborz-Azerbaijan micro-continent, and that the Alborz-Azerbaijan Tertiary magmatism was the result of this subduction (Azizi and Jahangiri 2008).

The overall petrography, petrology and geochemistry of the Kamtal Intrusion led to the conclusion that the parent magma of this body was derived from a lithospheric mantle source by subduction-related processes. The data indicate that the lithospheric mantle was affected by slab-related hydrous fluid resulting from the subduction. On this basis the following scenario (Fig. 18) for formation of the Kamtal Intrusion (Qaradagh Batholith) is assumed:

The Sanandaj-Sirjan island arc had been formed as a result of the subduction of Neotethys oceanic crust during the Mesozoic. Subsequently a back-arc basin developed behind the Sanandaj-Sirjan Belt. This back-arc basin was subducted beneath the Central Iran block, and the Urumiyeh-Dokhtar magmatic belt formed along the continental margin of Central Iran. High-angle subduction in the northwest of Iran (Azizi and Jahangiri 2008) caused the development of an extensional tectonic regime in the Alborz-Azerbaijan micro-continent. The Khoy back-arc basin was the result of this extension. Subduction of Neotethys beneath Central Iran ended in the upper Cretaceous-Lower Paleocene with the collision of the Sanandaj-Sirjan island arc with the Central Iran block. During this period the Khoy back-arc basin began subduction to the northeast beneath the AlborzAzerbaijan micro-continent. The result of this subduction was the formation of 


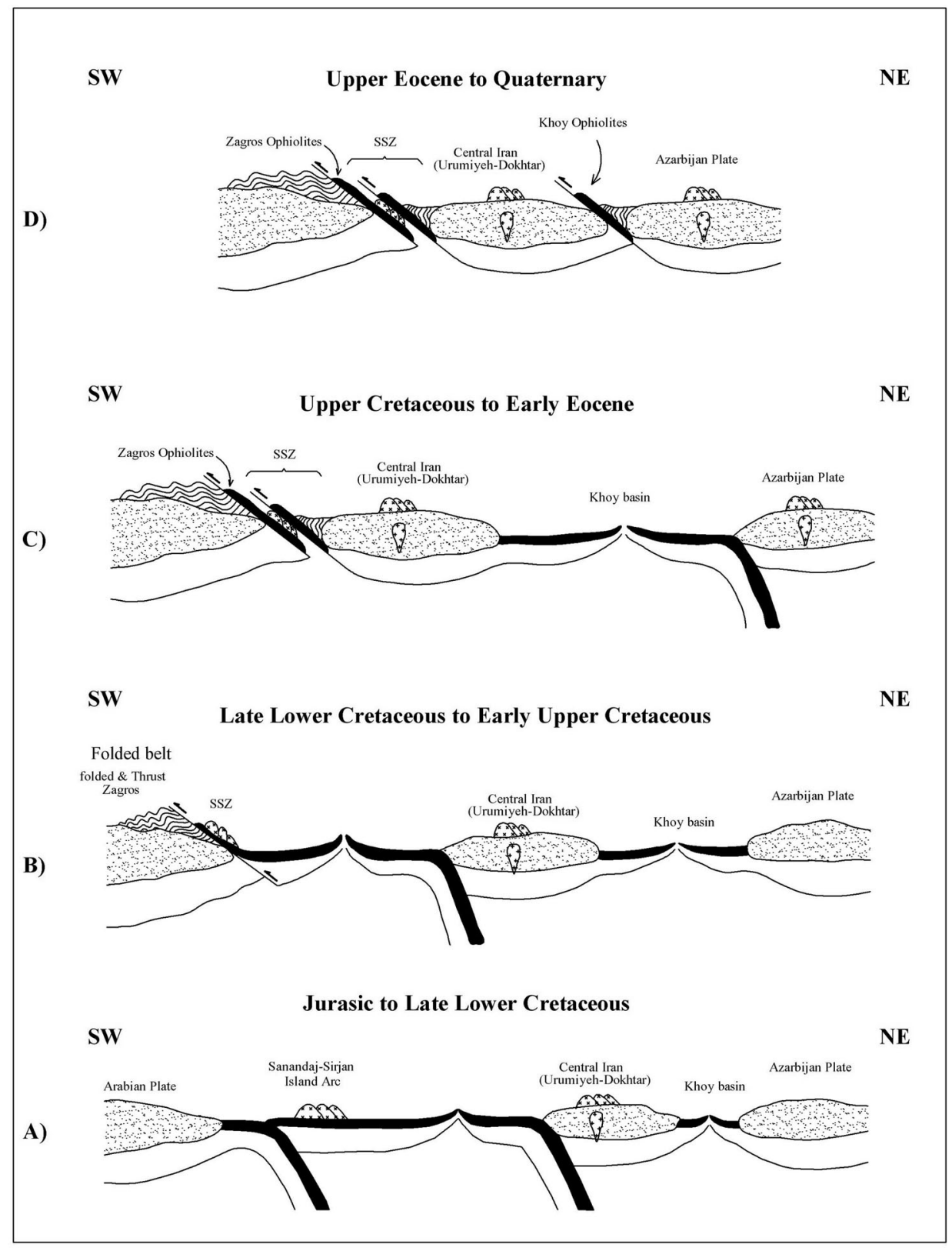

Central European Geology 53, 2010 
$\leftarrow$ Fig. 18

Schematic model for magmatism of study area (Mokhtari 2009): A) Subduction of Neotethys during the Mesozoic and formation of the Sanandaj-Sirjan as an island arc, B) Collision of the Arabian Plate with Sanandaj-Sirjan and subduction of the back-arc basin beneath Central Iran and formation of active continental arc (Urumiyeh-Dokhtar magmatic arc). As a result of this subduction, the Khoy back-arc basin opened with a NW-SE trend within the Central Iran Zone in the Azerbaijan area, C) Collision of the Arabian plate and Sanandaj-Sirjan with Central Iran (Urumiyeh-Dokhtar magmatic arc) in the Upper Cretaceous and subduction of the Khoy Basin beneath Alborz-Azerbaijan during the Upper Cretaceous-Eocene and formation of a magmatic arc in this zone, D) Collision of SanandajSirjan and the Urumiyeh-Dokhtar magmatic arc with the Alborz-Azerbaijan magmatic arc and change from compressional tectonic regime to extensional one

Alborz-Azerbaijan Tertiary magmatism. This subduction ended during the Lower Eocene.

Based on the above the main part of the Kamtal Intrusion (quartz-monzonite and gabbro) was probably the result of Khoy back-arc basin subduction beneath the Alborz-Azerbaijan micro-continent. The monzogranitic part formed after the end of subduction and the change from a compressional regime to an extensional one.

\section{Acknowledgements}

This study was financially by the Geological Survey of Iran (GSI) and Tarbiat Modares University (TMU). We would like to thank Dr Jiri Baburek and Dr. Radek Skoda of the Czech Geological Survey (CGS) for performing the EPMA analysis. Our gratitude is further expressed to Prof. Talat Ahmad of Delhi University for a first revision of this paper. Finally, we would like to thank Dr. Dobosi and Dr. Kiraly of the Hungarian Academy of Sciences for their revision, improvement and critical comments of this manuscript.

\section{References}

Abdel-Rahman, A.M. 1994: Nature of biotites from alkaline, calc-alkaline and peraluminous magmas. - Journal of Petrology, 35, pp. 525-541.

Aghanabati, S.A. 2004: Geology of Iran. - Geological Survey of Iran, 606 p.

Alavi, M. 1996: Tectonostratigraphic synthesis and structural style of the Alborz Mountain system in northern Iran. - Journal of Geodynamics, 21, pp. 1-33.

Azizi, H., A. Jahangiri 2008: Cretaceous subduction-related volcanism in the northern SanandajSirjan Zone, Iran. - Journal of Geodynamics, 45, pp. 178-190.

Barbarin, B. 1999: A review of the relationships between granitoid types, their origins and their geodynamic environments. - Lithos, 46, pp. 605-626.

Batchelor, R.A., P. Bowden. 1985: Petrogenetic interpretation of granitic rock series using multicationic parameters. - Chemical Geology, 48, pp. 43-55.

Chappell, B.W., A.J.R. White 1974: Two contrasting granite types. - Pacific Geology, 8, pp. 173-174.

Chappell, B.W., A.J.R. White 1992: I- and S-type granites in Lachlan Fold Belt. - Transactions of the Royal Society of Edinburgh, Earth Sciences, 83, pp. 1-26. 
Collins, W.J., S.D. Beams, A.J.R. White, B.W. Chappell 1980: Nature and origin of A-type granites with particular reference to south eastern Australia. - Contribution to Mineralogy and Petrology, 80, pp. 189-200.

Didier, J., J.L. Duthou, J. Lameyre 1982: Mantle and Crustal granites: Genetic classification of Orogenic granites and nature of their enclaves. - Journal of Volcanology and Geothermal Research, 14, pp. 125-132.

Ghazi, A.M., E.A. Pessagno, A.A. Hassanipak, S.M. Kariminia, R.A. Duncan, H.A. Babaie 2003: Biostratigraphic zonation and ${ }^{40} \mathrm{Ar} /{ }^{39} \mathrm{Ar}$ ages for the Neotethyan Khoy ophiolite of NW Iran. Paleogeography, Paleoclimatology and Paleoecology, 193, pp. 311-323.

Hassanipak, A.A., A.M. Ghazi 2000: Petrology, geochemistry and tectonic setting of the Khoy ophiolite, northwest Iran: implication for Tethyan tectonics. - Journal of Asian Earth Sciences, 18, pp. 109-121.

Irvine, T.N., W.R.A. Baragar 1971: A guide to the chemical classification of the common volcanic rocks. - Canadian Journal of Earth Science, 8, pp. 523-276.

Juteau, T. 2003: The ophiolites of Khoy (NW Iran): their significance in the Tethyan ophiolite belts of the Middle East. - Comptes Rendus Geoscience, 336/2 pp. 105-108..

Khalatbari-Jafari, M., T. Juteau, H. Bellon, H. Whitechurch, J. Cotton, M.H. Emami 2003: New geological, geochronological and geochemical investigations of the Khoy ophiolites and related formations, NW Iran. - Journal of Asian Earth Sciences, 23, pp. 507-535.

Maniar, P.D., P.M. Piccoli 1989: Tectonic discrimination of granitoids. - Geological Society of America Bulletin, 101, pp. 635-643.

Mehrpartou, M. 1997: Geological map of Syahrood in scale 1:100000. - Geological Survey of Iran.

Meinert, L.D. 1993: Igneous Petrogenesis and skarn deposits. - In: Kirkham, R.V., W.D. Sinclair, R.I. Thorpe, J.M. Duke (Eds): Mineral Deposit Modeling - Geological Association of Canada, Special Paper, 40, pp. 569-583.

Mirmohamadi, M.S. 1995: Geochemistry and petrology of Kamtal intrusion and its metamorphic aureole (East of Jolfa, NW Iran). - Unpublished M.S thesis, Tehran University, Iran.

Mokhtari, M.A.A. 2009: Petrology, geochemistry and petrogenesis of Qaradagh batholith (east of Syahrood, Eastern Azarbaijan) and related skarn, with considering mineralization. Unpublished Ph.D. thesis, Tarbiat Modares University, Tehran, Iran.

Muller, D., D.I. Groves 1997: Potassic igneous rocks and associated gold-copper mineralization. Second edition. - Springer Verlag, $242 \mathrm{p}$.

Pearce, J.A. 1982: Trace element characteristics of lavas from destructive plate boundaries. - In: Thorpe, R.S. (Ed.): Andesites. Wiley, New York, pp. 525-548.

Pearce, J.A. 1996: Sources and setting of granitic rocks. - Episodes, 19, pp. 120-125.

Rickwood, P.C. 1989: Boundary lines within petrologic diagrams which use oxide of major and minor elements. - Lithos, 22, pp. 247-264.

Sajona, F.G., R.C. Maury, H. Bellon, J. Cotton, M. Defant 1996: High field strength elements of Pliocene-Pleistocene island arc basalts Zamboanga Peninsula, Western Mindanao (Philippines). - Journal of Petrology, 37, pp. 693-726.

Shelly, D. 1993: Igneous and metamorphic rocks under the microscope. - Chapman and Hall, London, Glasgow, New York, 445 p.

Sun, S., W.F. McDonough 1989: Chemical and Isotopic Systematics of oceanic basalts: implications for Mantle Composition and Processes. - In: Saunders, A.D., M.J. Norry (Eds): Magmatism in the Ocean Basins, Spec. Publ. Vol. Geol. Soc. Lond., 42, pp. 313-345.

Sock, R.O., I.S.E. Carmichael, M. Rivers, M.S. Chiorso 1980: Ferric-ferrous equilibria in natural silicates liquids at 1 bar. - Contribution to Mineralogy and Petrology, 75, pp. 369-376.

Thieblemont, D., M. Tegyey 1994: Une discrimination geochimique des roches differenciees temoin de la diversite d'origine et de la situation tectonique des magmas. - Comptes Rendus de l'Academie des sciences, Paris, 319, pp. 87-94.

Wilson, M. 1989: Igneous petrology. - Chapman and Hall, London, 466 p. 